\title{
STRATEGI PENGEMBANGAN EKOWISATA BERBASIS EKONOMI LOKAL DALAM RANGKA PROGRAM PENGENTASAN KEMISKINAN DI WILAYAH KABUPATEN MALANG
}

\author{
Dias Satria \\ Fakultas Ekonomi Universitas Brawijaya
}

\begin{abstract}
In the era of sustainable development, alternative and sustainable tourism have become a great concern for local government. Sempu Island which is located in Kabupaten Malang is one of the interesting cases on how the Ecotourism concept could be combined to the local economic development and conservation issues. The aims of this paper are to gather information about the picture of Ecotourism practices in Sempu Island. Furthermore, it will formulate the strategic way to make ecotourism work well to the development of the local society.
\end{abstract}

Keywords: Sustainable development, ecotourism, Sempu Island and local economy.

\section{A. LATAR BELAKANG}

Pembangunan ekonomi daerah yang kuat dan berkelanjutan merupakan sebuah kolaborasi yang efektif antara pemanfaatan sumberdaya yang ada, masyarakat dan pemerintah. Dalam konteks ini, pemerintah sebagai regulator berperan strategis dalam mengupayakan kesempatan yang luas bagi masyarakat lokal untuk berpartisipasi penuh dalam setiap aktivitas ekonomi.

Salah satu upaya pemanfaatan sumberdaya lokal yang optimal adalah dengan mengembangkan pariwisata dengan konsep Ekowisata. Dalam konteks ini wisata yang dilakukan memiliki bagian yang tidak terpisahkan dengan upaya-upaya konservasi, pemberdayaan ekonomi lokal dan mendorong respek yang lebih tinggi terhadap perbedaan kultur atau budaya. Hal inilah yang mendasari perbedaan antara konsep ekowisata dengan model wisata konvensional yang telah ada sebelumnya.

Secara sederhana, konsep ekowisata menghubungkan antara perjalanan wisata alam yang memiliki visi dan misi konservasi dan kecintaan lingkungan. Hal ini dapat terjadi karena keuntungan finansial yang didapat dari biaya perjalanan wisata digunakan juga untuk kebutuhan konservasi alam serta perbaikan kesejahteraan penduduk lokal. Di sisi lain, konsep ekowisata juga diarahkan untuk mempertahankan kebudayaan lokal serta tidak melanggar Hak Asasi Manusia (HAM) dan pergerakan demografi.

Pergeseran konsep kepariwisataan dunia ke model ekowisata, disebabkan karena kejenuhan wisatawan untuk mengunjungi obyek wisata buatan. Oleh karena itu peluang ini selayaknya dapat dimanfaatkan secara maksimal untuk menarik wisatawan asing mengunjungi objek berbasis alam dan budaya penduduk lokal.

Dalam perkembangan kepariwisataan secara umum, muncul pula istilah sustainable tourism atau "wisata berkelanjutan". Wisata berkelanjutan dipandang sebagai suatu langkah untuk mengelola semua sumber daya yang secara sosial dan ekonomi dapat dipenuhi dengan memelihara integritas budaya, proses-proses ekologi yang mendasar, keragaman hayati, dan unsur-unsur pendukung kehidupan lainnya". Berdasarkan pemahaman diatas, maka pariwisata dipandang sebagai salah satu alternatif untuk meningkatkan pendapatan daerah. Apalagi pengoptimalan potensi ini di dasari 


\section{Journal of Indonesian Applied Economics \\ Vol. 3 No. 1 Mei 2009, 37-47}

bahwa pariwisata merupakan sektor yang lebih menekankan pada penyediaan jasa dengan mengoptimalkan potensi kawasan wisata.

Di wilayah Jawa Timur, pusat-pusat wisata telah berkembang dengan pesat seiring dengan semakin meningkatnya pendapatan masyarakat di wilayah ini. Beberapa tawaran wisata yang ada sangatlah beragam, mulai dari wisata bahari, pegunungan, agro, satwa dll. Di wilayah Kabupaten Malang tersimpan keaneka ragaman wisata yang sangat menarik, salah satunya ada wisata bahari yang ada di wilayah Sendang Biru, yaitu Pulau Sempu. Konsep pengembangan wisata yang ditawarkan di Pulau Sempu adalah konsep Ekowisata, dimana pengembangan wisata yang ada diselaraskan dengan isu-isu konservasi lingkungan dan pemberdayaan masyarakat lokal. Keunikan inilah yang coba dicapture dalam penelitian ini bahwa pengembangan wisata ini mampu memberikkan nilai lebih tidak hanya pada lingkungan dan ekonomi, namun juga terhadap social welfare masyarakat secara umum. Berangkat dari kondisi tersebut penelitian ini bertujuan untuk(1). Mengidentifikasi kekuatan ekonomi lokal yang berada di wilayah ekowisata di Kabupaten Malang dan (2). Menyusun strategi yang dapat mendorong pengembangan potensi ekowisata yang berbasis ekonomi lokal di Kabupaten Malang.

\section{B. KAJIAN TEORITIS}

\section{Ekowisata}

Pergeseran konsep kepariwisataan dunia kepada pariwisata minat khusus atau yang dikenal dengan ekowisata, merupakan sebuah peluang besar bagi negara kita dengan potensi alam yang luar biasa ini. Hal ini terjadi akibat kecenderungan semakin banyaknya wisatawan yang mengunjungi objek berbasis alam dan budaya penduduk lokal. Secara definitif, ekowisata yang didefinisikan sebagai suatu bentuk perjalanan wisata yang bertanggung jawab ke kawasan alami yang dilakukan dengan tujuan mengkonservasi lingkungan dan melestarikan kehidupan dan kesejahteraan penduduk setempat. memperlihatkan kesatuan konsep yang terintegratif secara konseptual tentang keseimbangan antara menikmati keindahan alam dan upaya mempertahankannya. Sehingga pengertian ekowisata dapat dilihat sebagai suatu konsep pengembangan pariwisata berkelanjutan yang bertujuan untuk mendukung upaya-upaya pelestarian lingkungan (alam dan budaya) dan meningkatkan partisipasi masyarakat dalam pengelolaannya.

Ekowisata merupakan perjalanan wisata ke suatu lingkungan baik alam yang alami maupun buatan serta budaya yang ada yang bersifat informatif dan partisipatif yang bertujuan untuk menjamin kelestarian alam dan sosial-budaya. Ekowisata menitikberatkan pada tiga hal utama yaitu; keberlangsungan alam atau ekologi, memberikan manfaat ekonomi, dan secara psikologi dapat diterima dalam kehidupan sosial masyarakat. Jadi, kegiatan ekowisata secara langsung memberi akses kepada semua orang untuk melihat, mengetahui, dan menikmati pengalaman alam, intelektual dan budaya masyarakat lokal.

Secara konseptul ekowisata dapat didefinisikan sebagai suatu konsep pengembangan pariwisata berkelanjutan yang bertujuan untuk mendukung upaya-upaya pelestarian lingkungan (alam dan budaya) dan meningkatkan partisipasi masyarakat dalam pengelolaan, sehingga memberikan manfaat ekonomi kepada masyarakat setempat. Sementara ditinjau dari segi pengelolaanya, ekowisata dapat didifinisikan sebagai penyelenggaraan kegiatan wisata yang bertanggung jawab di tempat-tempat alami dan atau daerah-daerah yang dibuat berdasarkan kaidah alam dan secara ekonomi berkelanjutan yang mendukung upaya-upaya pelestarian lingkungan (alam dan budaya) dan meningkatnkan kesejahtraan masyarakat setempat.

Aktivitas ekowisata saat ini tengah menjadi tren yang menarik yang dilakukkan oleh para wisatawan untuk menikmati bentuk-bentuk wisata yang berbeda dari biasanya. Dalam konteks ini wisata yang dilakukkan memiliki bagian yang tidak terpisahkan dengan upaya-upaya konservasi, pemberdayaan ekonomi lokal dan mendorong respek yang lebih tinggi terhadap perbedaan kultur atau budaya. Hal inilah yang mendasari perbedaan antara konsep ekowisata dengan model wisata konvensional yang telah ada sebelumnya. Konsep ekowisata menurut wikipedia memiliki 
karakteristik-karakteristik umum, antara lain: Tujuan perjalanan menyangkut wisata alam, Meminimalkan dampak yang ditimbulkan terhadap lingkungan, Membangun kesadaran terhadap lingkungan sekitar, Menghasilkan keuntungan finansial secara langsung yang dapat digunakan untuk melakukan konservasi alam, Memberikan keuntungan finansial dan memberikan kesempatan pada penduduk lokal, Mempertahankan kebudayaan lokal dan Tidak melanggar hak asasi mannusia dan pergerakan demografi.

Walaupun banyak nilai-nilai positif yang ditawarkan dalam konsep ekowisata, namun model ini masih menyisakan kritik dan persoalan terhadap pelaksanaanya. Beberapa kritikan terhadap konsep ekowisata antara lain:

1) Dampak negatif dari pariwisata terhadap kerusakan lingkungan. Meski konsep ecotourism mengedepankan isu konservasi didalamnya, namun tidak dapat dipungkiri bahwa pelanggaran terhadap hal tersebut masih saja ditemui di lapangan. Hal ini selain disebabkan karena rendahnya pengetahuan dan kesadaran masyarakat sekitar dan turis tentang konsep ekowisata, juga disebabkan karena lemahnya manajemen dan peran pemerintah dalam mendorong upaya konservasi dan tindakan yang tegas dalam mengatur masalah kerusakan lingkungan.

2) Rendahnya partisipasi masyarakat dalam Ekowisata. Dalam pengembangan wilayah Ekowisata seringkali melupakan partisipasi masyarakat sebagai stakeholder penting dalam pengembangan wilayah atau kawasan wisata. Masyarakat sekitar seringkali hanya sebagai obyek atau penonton, tanpa mampu terlibat secara aktif dalam setiap proses-proses ekonomi didalamnya.

3) Pengelolaan yang salah. Persepsi dan pengelolaan yang salah dari konsep ekowisata seringkali terjadi dibeberapa wilayah di Indonesia. Hal ini selain disebabkan karena pemahaman yang rendah dari konsep Ekowisata juga disebabkan karena lemahnya peran dan pengawasan pemerintah untuk mengembangkan wilayah wisata secara baik.

Pengembangan ekowista bahari yang hanya terfokus pada pengembangan wilayah pantai dan lautan sudah mulai tergeser, karena banyak hal lain yang bisa dikembangkan dari wisata bahari selain pantai dan laut. Salah satunya adalah konsep ekowisata bahari yang berbasis pada pemadangan dan keunikan alam, karakteristik ekosistem, kekhasan seni budaya dan karakteristik masyarakat sebagai kekuatan dasar yang dimiliki oleh masing-masing daerah. Selanjutnya kegiatan ekowisata lain yang juga dapat dikembangkan, antara lain: berperahu, berenang, snorkling, menyelam, memancing, kegiatan olahraga pantai dan piknik menikmati atmosfer laut.

Orientasi pemanfaatan pesisir dan lautan serta berbagai elemen pendukung lingkungannya merupakan suatu bentuk perencanaan dan pengelolaan kawasan secara merupakan suatu kesatuan yang terintegrasi dan saling mendukung sebagai suatu kawasan wisata bahari. Suatu kawasan wisata yang baik dan berhasil bila secara optimal didasarkan pada empat aspek yaitu: a) Mempertahankan kelestarian lingkungannya; b) Meningkatkan kesejahteraan masyarakat di kawasan tersebut; c) Menjamin kepuasan pengunjung dan d) Meningkatkan keterpaduan dan kesatuan pembangunan masyarakat di sekitar kawasan dan zona pengembangannya.

Selain keempat aspek tersebut, ada beberapa hal yang juga perlu diperhatikan untuk pengembangan ekowisata bahari, anatara lain : Aspek Ekologis, daya dukung ekologis merupakan tingkat penggunaan maksimal suatu kawasan; Aspek Fisik, Daya dukung fisik merupakan kawasan wisata yang menunjukkan jumlah maksimum penggunaan atau kegiatan yang diakomodasikan dalam area tanpa menyebabkan kerusakan atau penurunan kualitas; Aspek Sosial, Daya dukung sosial adalah kawasan wisata yang dinyatakan sebagai batas tingkat maksimum dalam jumlah dan tingkat penggunaan dimana melampauinya akan menimbulkan penurunanan dalam tingkat kualitas pengalaman atau kepuasan; Aspek Rekreasi, Daya dukung reakreasi merupakan konsep pengelolaan yang menempatkan kegiatan rekreasi dalam berbagai objek yang terkait dengan kemampuan kawasan. 


\section{METODE PENELITIAN DAN ANALISIS DATA}

Penelitian ini dipertimbangkan sebagai penelitian evaluasi, di mana akan melakukan evaluasi atas pelaksanaan program pembangunan. Penelitian evaluasi diartikan 'a process of determining whether a social intervention has produced the intended result'. Penelitian ini mengidentifikasi dan mengevaluasi strategi pengembangan ekowisata yang berbasis pada ekonomi lokal di Kabupaten Malang. Penelitian ini dilakukan dengan memadukan antara pendekatan dekriptif-evaluatif dan kualitatif.

Lingkup kegiatan ini adalah teridentifikasinya sekaligus pengembangan strateginya potensi ekowisata yang berbasis pada ekonomi lokal di Kabupaten Malang. Dalam penelitian deskriptif, proses analisis dan interpretasi data tidak hanya dilakukan pada akhir pengumpulan data atau berdiri sendiri, namun secara simultan juga dilakukan pada saat pengumpulan data di lapangan berlangsung, sehingga dalam penelitian kualitatif sering dikenal sebagai proses siklus. Setelah mendapatkan informasi, dilakukan analisis untuk mencari hipotesis kemudian dilakukan pengumpulan informasi berikutnya. Ini dimaksudkan untuk memperoleh kesesuaian dengan hipotesis sementara yang telah disusun, demikian terus berputar hingga ditemukan puncak informasi atau kejenuhan data. Selanjutnya, kegiatan dalam analisis data meliputi pencarian data, menatanya, membaginya menjadi satuan-satuan yang dapat dikelola, mensintesanya, mencari pola, menemukan apa yang penting dan apa yang dipelajari serta memutuskan apa yang dilakukan.

Metode kualitatif adalah "prosedur penelitian yang menghasilkan data-data deskriptif berupa kata-kata tertulis dan lisan dari orang-orang dan pelaku yang diamati." Pencarian data-data dilakukan dengan metode induktif, yang diberangkatkan dari fakta-fakta atau peristiwa umum kemudian ditarik generalisasi yang bersifat khusus. Sedangkan pengelolaan datanya digunakan metode reflektif. Komponen-komponen metode reflektif adalah: (a) perekaan, (b) penafsiran, (c) penilaian, (d) deskripsi, (e) pemahaman; dan (g) analisa. Kemudian, dalam berpikir reflektif induksi akan diawali dari fakta-fakta khusus dan menuju ke pernyataann umum yang menerangkan fakta-fakta itu. Kemudian dari ekplanasi yang bersifat umum tersebut diselidiki kembali faktafakta yang telah ada tadi untuk meyakinkan kebenaran ekplanasi yang telah dirumuskan (verifikasi).

Metode analisis data yang digunakan untuk menganalisis data pada penelitian ini alat analisis SWOT (Strong, Weakness, Opportunity, dan Threat). Analisis SWOT digunakan untuk mengidentifikasi relasi-relasi sumberdaya ekowisata dengan sumberdaya yang lain (Damanik dan Weber, 2006).

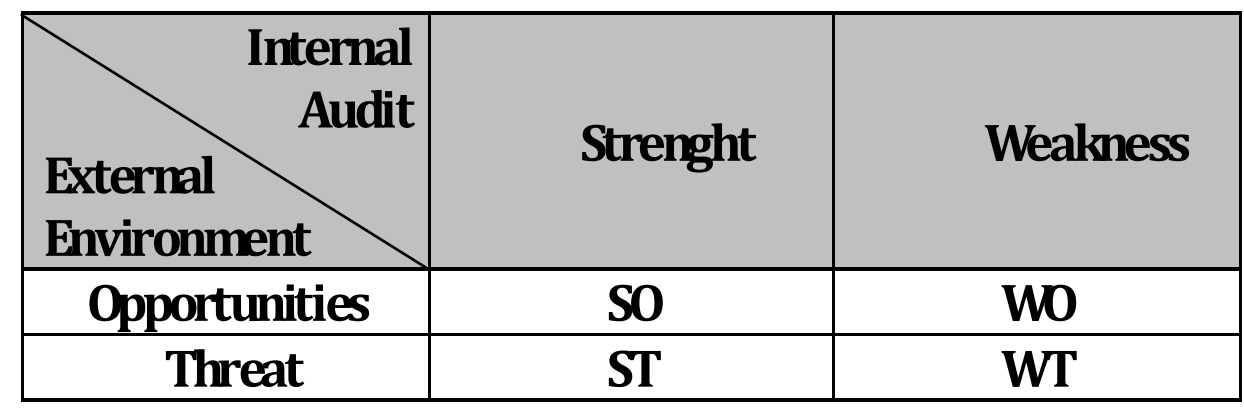

\section{Gambar 1. Matriks SWOT}

Keterangan:

SO: memanfaatkan kekuatan secara maksimal untuk meraih peluang.

ST: memanfaatkan kekuatan secara maksimal untuk mengantisipasi ancaman, dan

berusaha menjadikannya sebagai peluang.

WO: meminimalkan kelemahan, untuk meraih peluang.

WT: meminimalkan kelemahan untuk menghindar dari ancaman 


\section{HASIL DAN PEMBAHASAN}

\section{Gambaran umum obyek penelitian: Pulau Sempu}

Pulau sempu adalah suatu tempat wisata alam yang juga merupakan kawasan cagar alam berdasarkan SK. GB No. 46 Stbl. 1928 No. 69 tahun 1928 dengan luas 877 Ha. Dengan panorama alam indah serta flora dan fauna yang beraneka ragam, pulau sempu sudah seharusnya dijadikan cagar alam agar dapat dilestarikan. Pulau sempu merupakan sebuah pulau kecil yang langsung menghadap Samudra Hindia di satu sisi dan menghadap ke pulau Jawa di sisi lainya membuat pulau sempu terletak pada posisi yang unik, di satu sisi kita bisa melihat ganasnya ombak Samudra Hindia, di sisi lain kita bisa melihat Pulau jawa yang dipisahkan oleh air laut yang tenang. Selain letaknya yang unik dan strategis dan unik, Pulau Sempu juga menyinpan kekayaan alam yang beragam. Mulai dari kawasan pantai sampai danau air tawar semua terdapat di dalam Pulau yang hanya luas $877 \mathrm{Ha}$. Secara umum, ekosistem dalam pulau sempu dapat dikelompokan dalam empat type yang berbeda,

a) Ekosistem hutan Mangrove. Stuktur hutan mangrove ini sangat sederhana karena terdiri dari satu lapisan tajuk pohon dengan jenis-jenis yang relatif sedikit. Jenis-jenis tumbuhan yang umum di jumpai adalah Bakau (Rhizobhara sp), dan Api-api (Avicenia sp). Sedangkan jenis-jenis satwa yang umum di jumpai pada daerah perairan hutan mangrove adalah Ikan Glodok, Kepiting dan Udang.

b) Ekosistem Hutan Pantai. Areal hutan pantai Cagar Alam Pulau Sempu di bagian Utara, Barat dan Selatan Terutama pada pantai dengan pesisir yang landai. Jenis-jenis tumbuhan terdiri dari ketapang (Terminalia catapa), Baringtonia asitica, Waru laut (Hibicus tidiacus) dan pandan (Pandanum tectorius). Adapun jenis-jenis satwa liar yang sering di jumpai pada kawasan pantai ini antara lain : burung Elang Laut (Helicetus leucogaster), burung Dara Laut (Sterna albiforn), Biawak (Varanus sp), Umang Laut dan lain-lain.

Tabel 1. Beberapa unsur dan variabel dalam Analisis SWOT Ekowisata

\begin{tabular}{|c|c|}
\hline Unsur & Variabel \\
\hline Atraksi Alam & $\begin{array}{l}\text { Lokasi, jumlah, mutu, masalah, dan daya } \\
\text { tarik }\end{array}$ \\
\hline Atraksi budaya & $\begin{array}{l}\text { Lokasi, jenis, jumlah, mutu, masalah, daya } \\
\text { tarik }\end{array}$ \\
\hline Dampak Lingkungan yang Potensial & $\begin{array}{l}\text { Perubahan lingkungan fisik, ekologis, daya } \\
\text { dukung }\end{array}$ \\
\hline Aksesibilitas & Daya angkut, akses, mutu, frekuensi, ongkos \\
\hline Pasar & Daerah asal, tipe perjalanan, tipe kegiatan \\
\hline Usaha Jasa & $\begin{array}{l}\text { Mutu, kesesuaian dengan pasar, masalah } \\
\text { lain }\end{array}$ \\
\hline Informasi Wisata & $\begin{array}{l}\text { Mutu peta, buku panduan wisata, } \\
\text { pemaparan, } \\
\text { informasi }\end{array}$ \\
\hline Promosi & $\begin{array}{l}\text { Efektivitas advertensi, publisitas, } \\
\text { kehumasan, insentif, moda promosi }\end{array}$ \\
\hline Organisasi dan Kelembagaan & $\begin{array}{lcr}\text { Organisasi } & \text { terkait, } & \text { hubungan kerja, } \\
\text { kemitraan, } & \text { teamwork pengembangan } \\
\text { ekowisata } & & \end{array}$ \\
\hline Komitmen Pelaku Wisata & $\begin{array}{l}\text { Dukungan dari berbagai sektor, sikap publik } \\
\text { dan masyarakat lokal terhadap } \\
\text { pengembangan ekowisata }\end{array}$ \\
\hline
\end{tabular}

Sumber: Gunn dalam Damanik dan Weber, 2006. 
c) Ekosistem Danau. Daratan Cagar Alam Pulau Sempu memiliki dua buah danau yaitu Danau Telaga Lele dengan areal seluas $\pm 2 \mathrm{Ha}$, yang merupakan danau air tawar. Danau Segoro anakan dengan areal seluas \pm 4 Ha yang merupakan danau asin. Danau Air Tawar Telaga Lele terletak dibagian timur kawasan Cagar Alam, sedangkan Segoro Anakan berada dibagian Barat Daya. Masing-masing memiliki peranan yang pemting sebagai sumber air bagi kehidupan satwa liar, terutama pada musim kemarau.

d) Ekosistem Hutan Tropis Dataran Rendah. Tipe ekosistem ini menempati areal yang terluas dan tersebar hampir di seluruh kawasan, sehingga menjadi ciri utama dari kawasan Cagar Alam Pulau Sempu. Struktur hutan tropis ini di tandai dengan adanya tumbuh-tumbuhan yang terdiri dari tiga atau empat lapis tajuk pohon dengan komposisi yang beragam. Beberapa jenis pohon yang dominan yaitu Bendo (Artocarpus elasticus), Triwulan (Mishocarpatus sundaica), Wedang (Pterocarpus javanicus) dan Buchanania arborescens.

Dengan ekosistem yang ada di Pulau Sempu, flora dan fauna yang terdapat di sana juga khas dan berbeda dengan daerah yang lain. Untuk flora, Pulau Sempu memiliki \pm 223 jenis tumbuhan yang tergolong dalam 144 marga dan 60 suku. Dari 60 suku tersebut, telah diketahui lima suku (Moraceae, Euphorbiaeceae, Ancardiaceae, Annonaceae, Sterculiaceae), yang memiliki jumlah individu, jenis dan marga yang relatif cukup banyak. Sedangkan fauna, terdapat Satwa liar yang hidup di dalam kawasan Cagar Alam Pulau Sempu sekitar \pm 51 jenis yang terdiri dari 36 jenis Aves, 12 jenis mamalia dan 3 jenis reptil. Yang paling sering di jumpai diantaranya Babi hutan (Sus scopa), Kera hitam (Presbytis cristata), Belibis (Dendrosyqna sp) dan burung Rangkong (Buceros undulatus).

\section{Analisa Ekowisata di Pulau Sempu}

Pulau Sempu sebagai salah satu wilayah wisata yang menarik tidak hanya dikenal secara nasional, namun juga dikenal kiprahnya di dunia internasional. Bahkan beberapa website travelling rujukan dunia (www.travbuddy.com, www.planetmole.org, www.prlog.org, www.lomography.com. www.travelersfortravelers.com, www.wikimapia.org, etc) telah melansir Pulau Sempu sebagai tempat wisata alam yang layak untuk dikunjungi.

Tingginya ekspektasi wisatawan domestik dan internasional untuk dapat menikmati wisata bahari yang diberikkan oleh Pulau Sempu tentu harus didukung dengan support pemerintah yang lebih besar untuk menawarkan sebuah grand design dan kebijakan yang tepat dan berkelanjutan demi terjaganya keindahan ekowisata alam Pulau Sempu. Namun sebelum masuk pada tataran kebijakan atau policy maka akan disampaikan kondisi existing Ekowisata di pulau sempu dengan beberapa kriteria yang digunakan oleh Gunn dalam Damanik dan Weber (2006).

Secara umum Pulau Sempu menyimpan kekayaan alam yang sangat menarik untuk dikembangkan sebagai wilayah Ekowisata. Ada banyak faktor yang memperkuat mengapa wilayah ini relatif lebih terjaga dari masalah kerusakan alam, antara lain:

- Masyarakat sekitar masih resisten untuk menjadikan kawasan ini sebagai kawasan wisata konvensional seperti pembangunan Hotel, Resort dan pembangunan lainnya. Hal ini menjadikan wilayah Pulau Sempu tetap terjaga keasliannya.

- Akses masuk untuk menikmati keindahan Pulau Sempu di "Segoro anakan" tidaklah mudah untuk dilalui, dimana wisatawan harus melintasi wilayah hutan dengan berjalan kaki selama kurang lebih 2 jam.

- Wilayah Pulau Sempu masih menjadi program konservasi dan cagar alam pemerintah sehingga kekayaan alam didalamnya juga dilindungi oleh Pemerintah.

Dengan kekuatan ini maka pengembangan wilayah Pulau Sempuh sebagai tempat wisata sudah selayaknya dilakukkan oleh pemerintah, dengan tetap mempertahankan aspek kemasyarakatan, lingkungan dan ekonomi.

Dalam konteks ini kekuatan atau kelebihan yang dimiliki oleh Pulau Sempu, antara lain: pertama, Kekayaan alam yang masih alami dan natural. Dalam hal ini wisatawan dapat menikmati 
berbagai macam pengalaman petualangan yang menarik mulai dari penyeberangan, pelintasan hutan hingga sampai di “Segoroanakan". Di mulai dari penyebrangan menggunakan perahu nelayan tradisional, wisatawan dapat menikmati pemandangan laut dan aktivitas nelayan. Perjalanan ini ditempuh selama kurang lebih 15 menit. Selanjutnya perjalanan dilanjutkan dengan berjalan kaki melintasi hutan selama 2 jam. Wilayah yang masih tanah, berbatuan dan karang mewarnai perjalanan wisata hutan yang sangat menarik. Dalam perjalanan terakhir sebelum sampai di "Segoroanakan", wisatawan harus merayap di karang-karang selama 15 menit. Sebuah perjalanan adventure yang menarik dan sedikit berbahaya karena melewati tebing-tebing yang cukup curam. Terakhir, perjalanan sampai di "Segoroanakan" sebuah tempat yang eksotis dimana wisatawan dapat menikmati sebuah pantai yang indah yang bersebalahan dengan lautan lepas, dan dibatasi oleh karang yang besar.

Selain kekayaan alami yang ditawarkan di Pulau Sempu, wisatawan juga dapat menikmati kehidupan nelayan yang sangat unik dan tradisional. Di tempat ini wisatawan dapat melihat bagaimana aktivitas nelayan, mulai dari pencarian ikan, pelelangan ikan hingga wisata kuliner hasil tangkapan nelayan. Hal inilah yang dapat menjadi daya tarik wisatawan untuk dapat menikmati wisata bahari yang lengkap di Pulau Sempu.

Namun terlepas dari kekuatan yang ada di wilayah Pulau Sempu sebagai tempat Ekowisata, terdapat juga kelemahan-kelemahan yang menjadi hambatan wilayah ini untuk maju. Permasalahanpermasalahan yang ada antara lain: Pertama, Jarak lokasi Pulau Sempu dari Kota Malang menjadikan wilayah ini masih belum menjadi pilihan utama wisatawan regional di wilayah Malang Raya. Selain itu jalan yang berliku dan jauh menjadikan wisata ke Pulau Sempu membutuhkan effort yang cukup besar.

Kedua, patut difahami bahwa kondisi infrastruktur dan fasilitas di sekitar Pulau Sempu (Sendang Biru) masih belum memadai. Hal ini dapat dilihat dari jalan-jalan di wilayah Sendang Biru yang sebagian masih rusak. Selain itu kondisi infrastruktur seperti WC umum juga masih belum memadai dan sangat buruk, menjadikan tempat ini kurang lengkap untuk mendukung kebutuhan dasar wisatawan.

Ketiga, peran pemerintah dan masyarakat untuk mengembangkan wilayah Pulau Sempu sebagai lokasi Ekowisata belum sepenuhnya berhasil. Hal ini dilihat dari belum adanya program khusus untuk mengembangkan wilayah kawasan ini menjadi lebih bernilai dan berbobot. Bahkan promosi gencar atas wilayah ini hanya dilakukkan oleh perusahaan-perusahaan travel domestic dan mancanegara, tanpa melibatkan pemerintah sebagai stakeholder terbesar. Selain itu masyarakat di wilayah Sendang biru hanya dominan berpartisipasi dalam pengantaran wisatawan dengan perahu ke lokasi Pulau Sempu, dan belum terbentuk untuk menjadi masyarakat wisata yang aktif.

Keempat, Pemerintah masih belum melakukkan upaya konservasi dan penjagaan wilayah ini dengan ketat. Hal ini dapat dilihat dari belum adanya upaya penegakkan hukum bagi wisatawan yang melakukan upaya perusakan alam, seperti: membuang sampah sembarangan dll.

Berangkat dari kelemahan dan kekuatan yang ada, pihak pemerintah lokal dan masyarakat selayaknya dapat mengembangkan wilayah ini untuk dapat mengambil peluang dan mengantisipasi ancaman yang mungkin muncul. Peluang wilayah Ekowisata sebagai pilihan wisata yang menarik dapat dilihat dari besarnya animo masyarakat Jawa Timur untuk menikmati pilihan wisata yang berbeda dari biasanya, baik untuk kebutuhan outbond, training hingga edukasi. Selanjutnya wilayah Kota Malang yang populer dengan icon Kota pendidikan seharusnya dapat menjadikan Pulau Sempu sebagai peluang wisata bagi siswa maupun mahasiswa, karena jenis wisata ini sangat digemari oleh kaum muda. Meski begitu, ancaman yang ada pun juga harus dapat diantisipasi dengan baik oleh pemerintah lokal dan masyarakat, karena dengan semakin berkembangnya wilayah ini sebagai wilayah wisata akan menimbulkan kerusakan alam yang serius jika tidak ditangani dan diawasi dengan ketat. 


\section{Journal of Indonesian Applied Economics}

Vol. 3 No. 1 Mei 2009, 37-47

\section{Kebijakan Pengembangan Ekowisata di Pulau Sempu}

Dengan melihat segala potensi yang ada di kabupaten Malang, terutama kondisi di daerah Pulau Sempu, ada beberapa hal yang mesti dilakukan oleh pengambil kebijakan, untuk pengembangan ekowisata di kawasan Pulau sempu :

1. Penguatan konsep ecotourism bagi Pulau Sempu. Pulau Sempu yang memiliki potensi wisata alam yang sangat menarik perlu dikembangkan secara lebih serius oleh Pemerintah. Hal ini dilakukkan demi meningkatkan nilai ekonomis wilayah ini bagi penguatan ekonomi masyarakat sekitar. Namun untuk mengurangi dampak yang negatif terhadap kerusakan lingkungan maka diperlukan sebuah upaya khusus untuk menanggulanginya. Salah satu konsep yang tepat untuk mengatasi masalah ini adalah dengan mengembangkan konsep Ecotourism di Pulau Sempu. Dalam konteks ini maka wisata Pulau Sempu akan diarahkan sedemikian rupa agar pengembangannya tidak menganggu atau selaras dengan upaya konservasi lingkungan serta berdampak positif bagi pengembangan ekonomi lokal.

Pengembangan ekonomi lokal dilakukkan selain untuk menopang keberlanjutan konservasi juga diperlukan untuk mendorong kesejahteraan masyarakat sekitar. Namun dalam mengembangkan dan menguatkan konsep Ecotourism untuk mengembangkan ekonomi lokal diperlukan sebuah pemahaman yang tepat pada masyarakat dan pemerintah lokal. Hal ini dilakukkan agar pemerintah lokal dan masyarakat bisa berperan aktif dan menjadi stakeholder yang berkepentingan terhadap pengembangan wilayah ini. Salah satunya adalah dengan mengembangkan sebuah unit-unit ekonomi (BUMDES-Badan Usaha Milik Desa) dan Koperasi untuk mendukung aktivitas dan

\section{Tabel 2. Analisis SWOT Ekowisata Pulau Sempu}

\begin{tabular}{|c|c|}
\hline KEKUATAN (STRENGTH) & PELUANG (OPPURTUNITY) \\
\hline $\begin{array}{l}\text { - Kekayaan alam dan pemandangan yang } \\
\text { relatif alami di wilayah Pulau Sempu } \\
\text { dapat menjadi keunggulan/atraksi yang } \\
\text { sangat menarik bagi wisatawan yang } \\
\text { datang. } \\
\text { - Kehidupan masyarakat Nelayan yang } \\
\text { unik dapat menjadi daya tarik wisata } \\
\text { tersendiri. } \\
\text { KELE MAHAN ( WEAKNESSES) } \\
\text { - Jauhnya lokasi Pulau sempu dari Kota } \\
\text { Malang dan berkelak-keloknya jalan } \\
\text { menujukesana. } \\
\text { - Infrastruktur jalan yang sangat buruk di } \\
\text { wilayah daerah sendang biru. } \\
\text { - Sulitnya akses atas air bersih di wilayah } \\
\text { Pulau Sempu. } \\
\text { Masyarakat di wilayah Sendang Biru } \\
\text { belum terbentuk image sebagai wilayah } \\
\text { Ekowisata. } \\
\text { Peran pemerintah lokal dalam } \\
\text { melakukkan upaya-upaya konservasi } \\
\text { dan pengawasan masih sangat rendah }\end{array}$ & $\begin{array}{l}\text { - Wilayah wisata Pulau Sempu dapat } \\
\text { menjadi pilihan tempat Ekowisata yang } \\
\text { menarik di wilayah Jawa timur. } \\
\text { - Tingginya Jumlah Mahasiswa di Wilayah } \\
\text { Jawa timur mendorong pasar Ekowisata } \\
\text { yang lebih luas. } \\
\text { ANCAMAN (THREAT) } \\
\text { - Pengembangan Wilayah Sendang Biru } \\
\text { untuk menjadi pelabuhan Cargo } \\
\text { internasional dapat menjadi ancaman } \\
\text { lingkungan. }\end{array}$ \\
\hline $\begin{array}{l}\text { kebutuhan para wisatawan, mulai dari } \\
\text { (Kapal Nelayan), Penginapan, Parkir } \\
\text { 2. Mendorong linkage dengan travel ur } \\
\text { wisata tidak bisa dilepaskan dari keber } \\
\text { pemandu wisata dan agen wisata n } \\
\text { berhubungan dengan para wisatwan a } \\
\text { mengembangkan suatu kawasan ekow } \\
\text { jauh. pemandu wisata dan agen perja }\end{array}$ & $\begin{array}{l}\text { It usaha makanan, Souvenir, MCK, penyebrangan } \\
\text { gga Pemandu wisata. } \\
\text { agen perjalanan). Pengembangan suatu kawasan } \\
\text { a para pemadu wisata dan agen perjalanan. Karena } \\
\text { ipakan ujung tombak terdepan yang langsung } \\
\text { stakeholder, sehingga untuk lebih mudah dalam } \\
\text { a maka diperlukan partisipasi mereka secara lebih } \\
\text { an bisa dikontrol. Selain itu, keinginan dari para }\end{array}$ \\
\hline
\end{tabular}


wisatawan dapat lebih mudah ditangkap, sehingga pengembangan ekowisata lebih terarah dan sesuai dengan keinginan stakeholder.

Namun dalam pengembangan hubungan dengan agen perjalanan diperlukan sebuah kesepakatan tentang konsep Ecotourism yang dikembangkan di wilayah ini. Hal ini dimaksudkan agar tawaran paket wisata yang diberikan tidak menggangu upaya konservasi alam yang juga dilakukkan di wilayah ini. Selain itu pihak pemandu perjalanan juga diharapkan tidak memisahkan diri untuk kepentingan pemberdayaan masyarakat lokal dalam mendukung Ekowisata.

3. Mendorong partisipasi dan pemberdayaan masyarakat Wisata. Masyarakat lokal sebenarnya bukanlah hambatan bagi pengembangan Ekowisata, karena peran mereka seharusnya tidak terpisahkan dalam program-program wisata. Pengelolaan berbasis masyarakat ini merupakan salah satu pendekataan pengelolaan alam yang meletakkan pengetahuan dan kesadaran lingkungan masyarakat lokal sebagai dasar pengelolaanya. Ditambah adanya transfer diantara generasi yang menjadikan pengelolaan menjadi berkesinambungan menjadikan cara inilah yang paling efektif, dibanding cara yang lainya.

Secara umum sudah dibahas sebelumnya bahwa pengelolaan sumberdaya wilayah pesisir dan lautan efektif adalah yang berbasis pada masyarakat. Nikijuluw (1994) berpendapat pengelolaan berbasis masyarkat merupakan salah satu pendekataan pengelolaan alam yang meletakkan pengetahuan dan kesadaran lingkungan masyarakat lokal sebagai dasar pengelolaanya. Ditmabah adanya transfer diantara generasi yang menjadikan pengelolaan menjadi berkesinambungan menjadikan cara inilah yang paling efektif, disbanding cara yang lainya. Namun, masyarkat juga jangan sampai dilepaskan sendirian untuk mengelola semuanya. Karena sudah diketahui bersama, bahwa salah satu masalah utama yang dihadapi dalam pengelolaan ekowisata di Indonesia adalah masalah kualitas Sumber Daya Manusia (SDM), karena ketidakmerataan pendidikan yang diperoleh. Salah satu hal yang bisa dilakukan dengan melibatkan pemerintah lokal dalam pengeloalaan, seperti dalam gambar 2 .

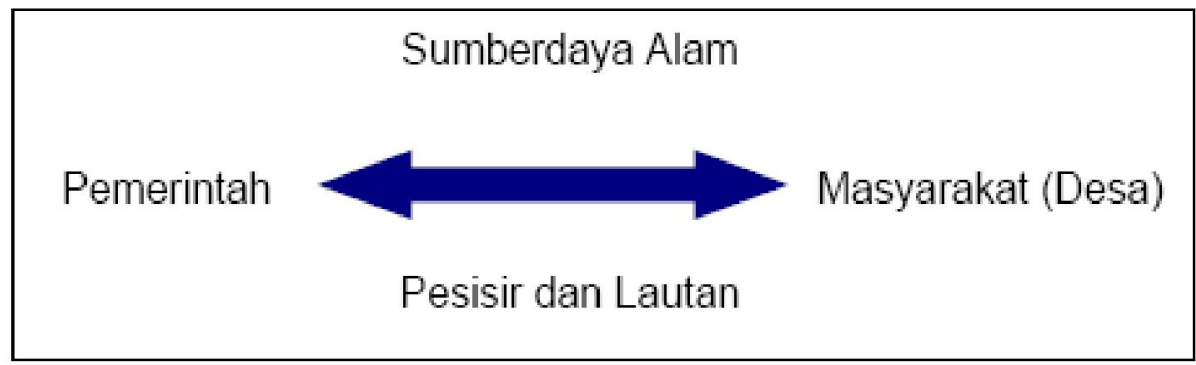

\section{Gambar 2. Pengelolaan Sumberdaya Pesisir berbasis masyarakat dengan melibatkan pemerintah}

4. Mendorong unit-unit usaha yang strategis. Dengan semakin berkembangnya wilayah Pulau Sempu sebagai tempat Ekowisata, maka kebutuhan akan unit-unit usaha penyokong juga diperlukan seperti tempat penginapan, tempat parkit, usaha souvenir, toko serba ada (perancangan), tempat MCK, restaurant hingga jasa penyeberangan dengan kapal Nelayan. Semua unit-unit usaha ini diharapkan dapat berada di wilayah sendang biru dan tidak beroperasi di Pulau Sempu, karena diperlukan untuk mempertahankan kemurnian alam hayati dan sisi naturalisme yang tinggi.

Dalam konteks pengembangan unit-unit usaha juga diperlukan sebuah bentuk kelembagaan yang baik dengan mengembangkan sisi sosial ekonomi secara bersamaan (social enterpreneurship) seperti konsep Koperasi dan BUMDES (Badan Usaha Milik Desa).

5. Melakukan promosi yang gencar. Berkembangnya kawasan wisata Pulau Sempu akan semakin baik jika promosi yang dilakukkan juga gencar, hal ini dilakukkan guna menanamkan image wisata yang kuat di wilayah Pulau Sempu. Promosi yang gencar selain dapat dikaitkan dengan 
program-program yang ada dalam agen perjalan juga dapat dilakukkan dengan mempromosikannya melalui website.

6. Mendorong partisipasi unit aktivitas mahasiswa Pencinta Alam untuk melakukkan program konservasi secara berkala. Peningkatan upaya konservasi di wilayah Pulau Sempu selain dapat dilakukkan oleh pemerintah lokal juga dapat dikoordinasikan dengan unit-unit aktivitas mahasiswa Pecinta Alam dari berbagai perguruan tinggi di Jawa Timur. Hal ini dapat dilakukkan dengan terus melakukkan aktivitas-aktivitas yang ramah dengan lingkungan, seperti menjaga cagar alam dan kebersihan serta melakukkan pengawasan atau pemanduan terhadap wisatawan-wisatawan yang datang.

7. Melakukkan Investasi MCK, Kebersihan dan Air Bersih di wilayah "Segoro-anakan". Infrastruktur dasar yang belum ada di wilayah Pulau Sempu (Segoro-anakan) adalah MCK dan air bersih. Hal ini menjadi masalah utama bagi wisatawan yang sedang melakukkan perkemahan disekitar wilayah "Segoro-anakan". Jika tidak ditangani dengan serius hal ini dapat mengganggu kebersihan, keindahan serta mengancam kerusakan alam yang ada di wilayah "Segoro-anakan".

\section{E. KESIMPULAN DAN REKOMENDASI}

1. Pulau Sempu merupakan wilayah wisata yang dapat dikembangkan menjadi ekowisata yang menarik bagi wisatawan domestik dan internasional yang ingin menikmati konsep ekowisata.

2. Pengembangan ekowisata di wilayah Pulau Sempu hendaknya dapat diselaraskan dengan kondisi sosial dan ekonomi masyarakat, serta tidak berbenturan dengan upaya konservasi yang telah dilakukkan pemerintah daerah di wilayah ini.

3. Pengembangan ekowisata di Pulau Sempu semaksimal mungkin harus dapat melibatkan masyarakat dan pemerintah daerah secara optimal dalam setiap proses-proses didalamnya. Hal ini dilakukkan guna memberikkan ruang yang luas bagi masyarakat setempat untuk menikmati keuntungan secara ekonomi dari pengembangan ekowisata di wilayah ini.

4. Peningkatan kerjasama perlu untuk ditingkatkan dengan institusi atau lembaga terkait, seperti agen perjalanan dan unit aktivitas mahasiswa pecinta alam, guna melahirkan ide-ide yang kreatif guna pengembangan wilayah ekowisata. Selain itu keterlibatan mereka juga diharapkan untuk memperkuat konsep ekowisata di wilayah Pulau Sempu.

\section{DAFTAR PUSTAKA}

Chafid Fandeli, 1997. Dasar-dasar Manajemen Kepariwisataan Alam, Yogyakarta: Liberti.

Connel, Joan at al., 1979. Migration From Rural Areas, The Evidance from Villages Studies, Delhi: Oxford University Press.

Damanik, Janianton dan Helmut F. Weber. 2006. Perencanaan Ekowisata: Dari Teori ke Aplikasi. PUSPAR UGM dan Penerbit Andi. Yogyakarta.

Daulay Harmony, 2002. Pergeseran Pola Relasi Gender di Keluarga Migran, Penyunting Abdul Masrur, Yogyakarta: Penerbit Galang Press.

Hadinoto, 1997. Perencanaan Pengembangan Destinasi Pariwisata, Jakarta:PT. Gramedia

Hagues Paul dan Haris, 1985. Sampling dan Statistik (Penterjemah Yulianto), Jakarta: LPPM dan PT Pustaka Binaman Pressindo.

Hari Karyono, 1997. Kepariwisataan, Jakarta: Penerbit PT. Gramedia Widisauna Indonesia. 
Kusmayadi, Sugiarto E, 2000. Metodologi Penelitian Dalam Bidang Kepariwisataan, Jakarta: PT Gramedia Pustaka Utama.

Liem Bik Gwat, J. G., 1997. Bertandang Memandang Kehidupan dan K e m a t i a $\mathrm{n} D$ a l a $\mathrm{m}$ Kepariwis-taan Toraja (Kajian tentang Kahidupan Masyarakat Toraja Menghadapi Pariwisata Budaya di Tanah Toraja, Salatiga: Tesis UKSW

Marpaung Happy, 2000. Pengetahuan Kepariwistaan, Bandung: Alfabeta.

Mchintos, Robert W and Charles R Goeldner, 1990. Tourism: Principles,

Practice, Philosophies, New York: Jogn Wiley and Sons Inc.

Mira P. Gunawan, 1999. Pariwisata Indonesia, Berbagai Aspek dan Gagasan Pembangunan, Bandung: Penerbit Lembaga Penelitian ITB.

Moeljarto Tjokrowinoto.2002. Pembangunan Dilema dan Tantangan, Yogyakarta: Pustaka Pelajar.

Moleong, Lexy J. 2005. Metodologi Penelitian Kualitatif. PT Remaja Rosdakarya. Bandung. 